\title{
Iowa Teachers among the Freedpeople of the South, 1862-1876
}

\author{
RONALD E. BUTCHART AND AMY F. ROLLERI
}

IN 1861, a movement began in the North and the South that struggled quietly to achieve its goals amid the roar and alarm of civil war. Largely forgotten today, that movement, eclipsed by news of battles, deaths of sons and brothers, and the agony of a nation breaking asunder, was the unprecedented effort by former slaves to find teachers, build schools, and gain a modicum of literacy and learning as rapidly as they could. From the earliest days of the Civil War, southern African Americans sought access to formal education for themselves and their children as an earnest of emancipation. In response, northern teachers, including more than a hundred Iowans, hurried into the South behind the Union forces to bring literacy and numeracy to the former slaves. ${ }^{1}$

Before the war, teaching African Americans to read was a criminal offense against the established order in most of the slave states. A fugitive literacy persisted among slaves and free

We gratefully acknowledge a research grant from the State Historical Society of Iowa that made possible a portion of the research reported here. We also express our particular thanks to Patricia Pierce Patterson and Lloyd Patterson of the Iowa Yearly Meeting of Friends for their graceful and generous assistance.

1. The story of freedmen's education is detailed in Ronald E. Butchart, Northern Schools, Southern Blacks, and Reconstruction: Freedmen's Education, 1862-1875 (Westport, CT, 1980); Robert C. Morris, Reading, 'Riting, and Reconstruction: The Education of Freedmen in the South, 1861-1870 (Chicago, 1981); and Jacqueline Jones, Soldiers of Light and Love: Northern Teachers and Georgia Blacks, 1865-1873 (Chapel Hill, NC, 1980). See also Henry L. Swint, The Northern Teacher in the South, 1862-1870 (1941; reprint, New York, 1967).

THE ANNALS OF IOWA 62 (Winter 2003). (C) The State Historical Society of Iowa, 2003. 
blacks, nonetheless, through clandestine schools, secret lessons, and stolen study; and bondage nurtured an abiding hunger for free access to learning and the social authority of literacy. ${ }^{2}$ From the beginning of the war and the effective emancipation and selfemancipation of the slaves, well before legal emancipation, that hunger led the freedpeople to create schools for themselves and to flock to schools created by northern aid. The movement to extend literacy to the freedpeople was, then, both a self-initiated effort on the part of southern blacks, and a humanitarian response on the part of northern aid societies and their teachers. ${ }^{3}$ Throughout Reconstruction, the former bondspeople's pleas for teachers and books perpetually overwhelmed the resources of the aid societies and outstripped the federal government's underfunded and short-lived response, the Bureau of Refugees, Freedmen, and Abandoned Lands. ${ }^{4}$

2. See especially Carter G. Woodson, The Education of the Negro Prior to 1861, 2d ed. (Washington, DC, 1919); Henry Allen Bullock, A History of Negro Education in the South: From 1619 to the Present (Cambridge, MA, 1967), 1-15; Janet Cornelius, "'We Slipped and Learned to Read': Slave Accounts of the Literacy Process, 1830-1865," Phylon 44 (1983), 171-86; idem, "When I Can Read My Title Clear": Literacy, Slavery, and Religion in the Antebellum South (Columbia, SC, 1991); and Joyce L. Harris, Alan G. Kamhi, and Karen E. Pollock, eds., Literacy in African American Communities (Mahwah, NJ, 2001).

3. Historians have traditionally focused on the work of northern agencies and individuals, implying, intentionally or not, that northern whites acted, southern blacks reacted. Black initiative in the education movement is explored in James D. Anderson, The Education of Blacks in the South, 1860-1935 (Chapel Hill, NC, 1988), 4-32; Butchart, "'We Best Can Instruct Our Own People': New York African Americans in the Freedmen's Schools, 1861-1875," AfroAmericans in New York Life and History 12 (1988), 27-49; and Karin L. Zipf, "'Among These American Heathens': Congregationalist Missionaries and African American Evangelicals during Reconstruction, 1865-1878," North Carolina Historical Review 74 (1997), 111-34.

4. The inability of the aid societies to meet the southern black demand for schools is documented in the sources cited in note 1 . The traditional history of the Freedmen's Bureau is George R. Bentley, A History of the Freedmen's Bureau (Philadelphia, 1955). Bentley's interpretation has been thoroughly revised by a number of state-level studies in the past two decades, however. See, for example, Paul A. Cimbala, Under the Guardianship of the Nation: The Freedmen's Bureau and the Reconstruction of Georgia, 1865-1870 (Athens, GA, 1997); Barry A. Crouch, The Freedmen's Bureau and Black Texans (Austin, TX, 1992); William L. Richter, Overreached on All Sides: The Freedmen's Bureau Administrators in Texas, 1865-1868 (College Station, TX, 1991). See also William S. McFeely, Yankee Stepfather: General O. O. Howard and the Freedmen (New Haven, CT, 1968); and Claude F. Oubre, Forty Acres and a Mule: The Freedmen's Bureau and Black Land 
The northern work on behalf of the freedpeople was spearheaded by voluntary aid organizations. Some of them, such as the New England Freedmen's Aid Society or the Northwestern Freedmen's Aid Commission, were ad hoc, secular agencies, created within months of the outbreak of war to gather supplies, medicine, workers, and teachers to meet the immediate humanitarian crisis of the war refugees and to address the longerterm needs for education, work, and assistance. Others were missionary societies within Protestant denominations. Of those, some were long-established groups, including the venerable American Missionary Association (originally interdenominational but, through the 1860s, increasingly a Congregationalist agency) and the American Baptist Home Mission Society. Others were hastily conceived church-sponsored committees created specifically to organize denominational aid for the freedpeople. Those groups included the Methodist Episcopal Freedmen's Aid Society, the Presbyterian Committee of Missions for Freedmen, and the United Presbyterian Church Board of Missions to the Freedmen. In all, more than 50 different agencies were at work at one time or another in the aid effort from the beginning of the Civil War until the end of Reconstruction, though not more than a dozen missionary societies, and none of the secular agencies, survived beyond $1872 .{ }^{5}$ Over half of the

Ownership (Baton Rouge, LA, 1978). The Bureau's educational work is detailed in Alton Hornsby Jr., "The Freedmen's Bureau Schools in Texas, 1865-1870," Southwestern Historical Quarterly 76 (1973), 397-417; Martin Abbott, "The Freedmen's Bureau and Negro Schooling in South Carolina," South Carolina Historical Magazine 57 (1956), 65-81; W. A. Lowe, "The Freedmen's Bureau and Education in Maryland," Maryland Historical Magazine 47 (1952), 29-39; Joe M. Richardson, "The Freedmen's Bureau and Negro Education in Florida," Journal of Negro Education 31 (1962), 460-67; and Butchart, Northern Schools, Southern Blacks, and Reconstruction, 97-114.

5. Butchart, Northern Schools, Southern Blacks, and Reconstruction, 3-96. The American Missionary Association was the first to extend aid to southern African Americans, the largest of the aid agencies, and the agency supporting the most teachers. Its work on behalf of the freedpeople is gracefully narrated in Joe M. Richardson, Christian Reconstruction: The American Missionary Association and Southern Blacks, 1861-1890 (Athens, GA, 1986). On other major missionary societies, see James P. Brawley, Two Centuries of Methodist Concern: Bondage, Freedom, and Education of Black People (New York, 1974); Inez Moore Parker, The Rise and Decline of the Program of Education for Black Presbyterians of the United Presbyterian Church, U.S.A., 1865-1970 (San Antonio, TX, 1977); and Fredrick 
more than 8,000 teachers known to have worked in southern black schools during the war and Reconstruction were northerners; all but a very few worked under the auspices of the various aid societies. $^{6}$

The aid societies recruited teachers through missionary magazines such as the American Missionary, monthly periodicals such as the American Freedman or the Freedmen's Record, or announcements from pulpits. ${ }^{7}$ Because the work was considered "missionary" work by the churches, and because the secular aid societies relied entirely on charitable contributions and hence had to keep their expenses at a minimum, the teachers' salaries were low, generally half to two-thirds the earnings of northern teachers in urban schools. The missionary societies consistently paid women teachers less than men-usually $\$ 15$ per month for women, \$25 and more for men-but the secular societies, along with the Quakers, equalized salaries early in the work. All aid

Richardson, "American Baptists' Southern Mission," Foundations 18 (1975), 13645; and Robert E. Thompkins, "Presbyterian Religious Education among Negroes, 1864-1891," Journal of the Presbyterian Historical Society 29 (1951), 145-71.

6. All data reported here regarding the teachers is drawn from the Freedmen's Teachers Project, Ronald E. Butchart and Amy F. Rolleri, project directors. The project has, to date, identified more than 8,250 individuals who taught for at least one month in the schools for freed slaves, 1861-1876, and amassed as much archival and prosopographic data on each teacher as possible. All figures reported remain tentative, pending the completion of the research, though we estimate that we have now identified over 90 percent of the teachers. The project is described more fully in Butchart, "Recruits to the 'Army of Civilization': Gender, Race, Class, and the Freedmen's Teachers, 1862-1875," Journal of Education 172 (1990), 76-87; early results of the research were reported in Butchart, "Perspectives on Gender, Race, Calling, and Commitment in Nineteenth-Century America: A Collective Biography of the Teachers of the Freedpeople, 1862-1875," Vitae Scholastica 13 (1994), 15-32.

7. The American Missionary, published monthly by the American Missionary Association, featured the freedmen's work for many years, along with the association's foreign missionary work. Others, such as the Episcopalian Spirit of Missions, gave less space to the southern work. Other major denominations recruited primarily through announcements from the pulpit and information provided in annual reports of their respective freedmen's aid committees. The American Freedman was published by the American Freedmen's Union Commission, an umbrella organization that coordinated the work of the major secular aid societies from 1866 to 1869; Freedmen's Record was published by the New England Freedmen's Aid Society, the longest-lived of the secular groups. For a full list of aid society publications, see Butchart, Northern Schools, Southern Blacks, and Reconstruction, 5-11. 
societies arranged for the teachers' board in addition to their salary. ${ }^{8}$

Teachers occasionally could stipulate where they were sent, at least to the extent of indicating whether they went to a border state or deeper into the South, but most assignments were made arbitrarily by the aid societies. Many of the teachers found themselves assigned to a locale with no established school. They had to spend their first weeks locating a building that could accommodate their class, gathering and organizing students who had no prior experience with the expectations of modern classroom life, and begging for books and slates from their sponsors, the government, and the few sympathetic southern whites. They usually found themselves with more students than they could accommodate; most found themselves teaching evening classes for working adults as well as managing overcrowded daytime classes. Those most adept at creating new schools were reassigned often so that the less aggressive could be assigned to an established school.'

Compared to the moral obligations the nation owed to its four million former slaves, the response was paltry, though nineteenth-century political ideology and economic theory and an unbowed southern planter class probably would have tolerated no more. ${ }^{10}$ The response amounted to not much more than a million dollars per year, all public and private agencies included, from the early 1860 s to the end of Reconstruction. The effort also represented the energies of a few thousand teachers, a disproportionate number of whom were themselves African Americans. Still, the story of the northern teachers who labored among the freedpeople is an important chapter in social history. The teachers chose, for shorter or longer periods, to set aside their normal routines to work among a despised people, usually becoming despised themselves for the duration of their labors. They worked and lived in deprived conditions, teaching in settings that give new meaning to current talk of "under-resourced

8. Butchart, Northern Schools, Southern Blacks, and Reconstruction, 122-23.

9. Ibid., 115-34.

10. Eric Foner, Reconstruction: America's Unfinished Revolution, 1863-1877 (New York, 1988). 
schools" and earning less teaching children and adults than they would have received in northern schools. They taught a race that confounded the racial beliefs of even the most dedicated abolitionists, for the ex-slaves' hunger for knowledge was more profound and unshakable than the teachers had ever experienced in northern white schools. To the surprise of many, the academic ability of black learners proved no different than that of white students. ${ }^{11}$

More than one hundred Iowans were among the hardy group who dedicated time to educating the freedpeople between the early years of the Civil War and the end of Reconstruction. Their story sheds light on Iowa's social history and the history of its relationship to Reconstruction. What we can learn of them troubles the emerging understanding of the state's stance on race, for although Iowa stands out as a state that moved from racially conservative policies by mid-century to one of the most racially progressive states in the Union a quartercentury later, proportionately very few Iowans worked among the freedpeople when compared to states with a less impressive history on racial issues. ${ }^{12}$

THE STORY of Iowa's teachers among the freedpeople must be pieced together from fragments to create a mosaic, for none of the teachers left more than a few letters, and most left no direct evidence. The story began in 1862 when Henry Rowntree, from Springdale, went to Mississippi to deliver relief supplies and organize schools in the South, though he apparently did not teach. The first white Iowan to begin teaching the freedpeople was Thomas Merrill, an army chaplain from Newton, who

11. Butchart, Northern Schools, Southern Blacks, and Reconstruction, 169-79; Jones, Soldiers of Light and Love, 58-76; Linda B. Selleck, Gentle Invaders: Quaker Women Educators and Racial Issues during the Civil War and Reconstruction (Richmond, IN, 1995), 67-90; Butchart, "Schooling for a Freed People: The Education of Adult Freedmen, 1861-1871," in Black Adult Education in the United States: An Historical Overview, ed. Leo McGee and Harvey Newfeldt (Westport, CT, 1990), 45-58; Randy J. Sparks, "'The White People's Arms Are Longer than Ours': Blacks, Education, and the American Missionary Association in Reconstruction Mississippi," Journal of Mississippi History 54 (1992), 1-27.

12. Robert R. Dykstra, Bright Radical Star: Black Freedom and White Supremacy on the Hawkeye Frontier (Cambridge, MA, 1993). 
took time from his daily routine to teach groups of ex-slaves. As a result of his work with the freedpeople, the army appointed him to the newly created office of Superintendent of Freedmen in Huntsville, Alabama, in 1863 and 1864. Shortly after Merrill began his work, Lucinda Humphrey traveled from Tipton to teach in the first black school in Memphis, Tennessee, in defiance of the South's ban on educating slaves. ${ }^{13}$

Humphrey's experiences reflect the primitive conditions under which the early teachers labored. Lacking primers, she procured from a hospital "several sheets of paper fastened together, on which are printed in large type, choice passages of scripture." Thus provisioned, she began teaching letters and words. "My pointer was a rod which had formerly striped the back of my best pupil," she wrote. "'Not much did I tink,' said he, 'dis yere rod would eber point out to me, de words of 'ternal life.'" As an experienced teacher, Humphrey drew on what were, for her day, the most modern pedagogical methods, including "object teaching" and whole-group oral instruction, antidotes to traditional education's heavy reliance on textbooks and individual recitations. She found that oral instruction initially violated some of her students' preconceptions of proper teaching, yet she could report success with a very large class.

The oral instruction, they did not at first understand.... One who had been employed in some way about a school-house, thought it "mighty diffrent from the Secesh teachin" and much to my annoyance, assured the rest that "dey neber could learn nuffin widout lookin' on no books." But when they turned to their books, to their great astonishment, they could spell words which they were required to spell over and over again until they had learned them and could call them as readily as the letters composing them.

13. Thomas Merrill to George Whipple, 10/15/1864, letter \#40992, American Missionary Association Archives, Amistad Research Center, Tulane University, New Orleans (hereafter correspondence in this collection is cited as AMA \#). In the Mississippi valley, military authorities appointed Superintendents of Freedmen to deal with the humanitarian problem created by the thousands of slaves fleeing to Union lines. See John Eaton, Grant, Lincoln, and the Freedmen (New York, 1907); American Missionary 7 (May 1863), 115-16; [Joseph Warren], Reports and Extracts Relating to Colored Schools in the Department of the Tennessee and State of Arkansas, November 30, 1864 (Memphis, TN, 1864), 5-6; Mary H. Porter, Eliza Chappell Porter: A Memoir (Chicago, 1892), 17. Regarding Rowntree, see note 24 below. 
When formed into a sentence they were required to name them, and as the idea contained in the sentence came up before their minds, the great bug-bear of learning to read vanished, and they pressed right on with amazing rapidity. Great care was taken to lead them on step by step, never allowing them to fall back, and in two months time, fifty of the one hundred pupils had learned to read quite well. ${ }^{14}$

Humphrey taught for two years in Memphis, during which time she met and married the local superintendent of freedmen. ${ }^{15}$

In spring 1863, Salifia A. Duke, a 23-year-old shoemaker, left his wife and small child in Keokuk for a few months to follow the Union forces into Louisiana. He intended to help muster regiments from among the freed slaves, but found that the army had enough officers for the black forces. He turned his attention instead to teaching the freed slaves, "and with a colored Teacher (Margret Robinson) Ex. Slave, an old spelling book (found in the neighborhood) and a black board I had made for the school, we had a school of 40 schollars." His subsequent claim to have "started the first School for freed children on the Mississippi River" was a stretch, though he certainly was among the earliest teachers. He taught at Goodrich Landing, Louisiana, for several months. Four years later he was in Arkansas attempting to organize other schools for former slaves, though whether he was successful is not yet known. ${ }^{16}$

Like Merrill, Duke, and Humphrey after her marriage, a few other early Iowa teachers among the freedpeople were either connected with the military and its allied agencies, such as the Christian Commission or the Sanitary Commission, or with government-sponsored operations intended to relieve the military of the burden of the black refugees-essentially the work coordinated by the superintendents of freedmen. Edwin Booth,

14. Lucinda Humphrey, undated letter from Memphis, printed in American Missionary 7 (May 1863), 115-16 (italics in original). The term Secesh in the second sentence was frequently used by the freedpeople to refer derisively to southern white secessionists and to the period prior to the Civil War.

15. Lucinda Humphrey Hay to George Whipple, 11/3/1864, AMA \#40999.

16. S. A. Duke to J. Miller McKim, 9/2/1867, American Freedmen's Union Commission Papers, Olin Library, Cornell University (hereafter cited as AFUC Papers, CU); 1860 Federal census, State of Iowa, Lee County, Keokuk City, Ward 14, 1233/1130, p. 164. 
from Mt. Pleasant, for example, graduated from Oberlin College in 1862 at 30 years of age and enrolled immediately in the Union forces. After serving for a year in the Mississippi valley, he taught for one year for the American Missionary Association (AMA) in Louisiana. ${ }^{17}$ Sarah A. Fullenwider, the wife of a soldier in an Iowa regiment, along with her sister, Francis J. Scott, established one of the first regimental schools for black soldiers in Vicksburg, Mississippi, where they taught for several months in 1863-64 before returning to Cedar Rapids; both had attended Cornell College in Mt. Vernon. ${ }^{18}$ At about the same time, L. A. Eberhart, also from Cedar Rapids, the wife of an army chaplain, took up teaching ex-slaves while her husband was stationed in Vicksburg and New Orleans. ${ }^{19}$ Mary T. Colton, a widow from Croton, had gone south in the service of the U.S. Sanitary Commission, then stayed to teach in black schools for at least two years in Alabama and Mississippi ${ }^{20}$ Helen M. Jones, another Oberlin student and an experienced teacher from Tabor, served in the Christian Commission during the war. She moved directly from that work to a school for African Americans in Brookhaven, Mississippi, in 1865, then to another black school in Louisville, Kentucky, where she taught for two more years. ${ }^{21}$

17. Seventy-fifth Anniversary General Catalogue of Oberlin College, 1833-1908 (Oberlin, OH, 1909), 99; Edwin Booth file, Grads and Formers Collection, Oberlin College Archives, Oberlin College, Oberlin, OH; Eighteenth Annual Report of the American Missionary Association and the Proceedings at the Annual Meeting (New York, 1864), 27 (hereafter cited as AMA, Annual Report). Booth subsequently returned to Oberlin and completed a master's degree.

18. Freedmen's Advocate 1 (May 1864), 17; S. Fullenwider to George Whipple, $10 / 13 / 1864$, AMA \#40990. Frances graduated from Cornell College in 1862, and was a teacher at the college, 1862-63; Sarah attended one year (1862). See Catalogue of Cornell College (Mt. Vernon, 1860), 14; ibid, 1861, [7]; ibid, 1862, [6], 14; and ibid, 1863, [4].

19. AMA, 18th Annual Report, 1864, 27; S. W. Magill to AMA, 1/13/1864, AMA \#71577; L. A. Eberhart to George Whipple, 3/19/1864, AMA \#71617; Eberhart to Whipple, 7/9/1864, AMA \#40971.

20. American Missionary 11 (April 1867), 78; Mary Colton to John G. Fee, 5/15/ 1865 , AMA \#39202. Colton taught one year for the AMA, then moved to Mississippi, where she continued to teach without a sponsor. Mary T. Colton to John M. Walden, 10/15/1867, AFUC Papers, CU.

21. Helen M. Jones to George Whipple, 6/15/1865, AMA \#112478; John Todd to "Secretaries of A.M.A.," 8/29/1865, AMA \#41103; Jones to W. E. Whiting, 7/26/1866, AMA \#41132C; AMA, 20th Annual Report, 1866, 34; American Mis- 
Most of the 28 Iowans who made their way into the South before the close of the Civil War, however, went independently of the military. Some were probably drawn by humanitarian impulses, while others were responding to a heritage of activism on behalf of African Americans. ${ }^{22}$ The latter included what would become, after the war, a flood of Iowa Quaker teachers, acting on their historic testimony against slavery and their long commitment to the education of African Americans. ${ }^{23}$ At least three Iowa Quakers had begun organizing schools and teaching before April 1865. As noted earlier, Henry Rowntree, a 49-yearold farmer and former businessman from Springdale, was working among the freedpeople in the South between 1862 and 1864, primarily in Mississippi. ${ }^{24}$ Jacob Adell Jr., a 33-year-old farmer

sionary 11 (April 1867), 76; ibid. 12 (April 1868), 77; 75th Anniversary General Catalogue of Oberlin College, 530.

22. Historians have long associated the freedpeople's teachers with abolitionists, though for an earlier generation of historians, the label was an epithet, not an honorific as it has been subsequently. In all cases, however, the very fact of working among the freedpeople was seen as evidence of abolitionist commitments. We have become skeptical of that logic. Nor are we comfortable with the easy assumption that membership in an antislavery church led to abolitionism, or that teaching for an abolitionist aid society indicated the teacher's own abolitionism. Many teachers displayed attitudes and actions that contradicted abolitionist beliefs; few expressed unequivocal abolitionist motivations. See Swint, Northern Teacher in the South; Clifton H. Johnson, "Abolitionist Missionary Activity in North Carolina," North Carolina Historical Review 40 (1963), 295-320; James M. McPherson, The Struggle for Equality: Abolitionists and the Negro in the Civil War and Reconstruction (Princeton, NJ, 1964), esp. 154-77, 386416; Jones, Soldiers of Light and Love, 18-27; Butchart, Northern Schools, Southern Blacks, and Reconstruction, 131-33.

23. John R. McKivigan, The War against Proslavery Religion: Abolitionism and the Northern Churches, 1830-1865 (Ithaca, NY, 1984), 44, 163, argues that the Quakers were among many sects to shun abolitionism as an antislavery tactic until the late 1850 s, but it is essential to distinguish tactical positions from historic stances and actions. The Quakers were at that time the only sect that compelled its members to emancipate all their slaves, and their efforts to secure the rights of northern free blacks and to educate them outstripped the efforts of all other churches. See also Thomas D. Hamm, The Transformation of American Quakerism: Orthodox Friends, 1800-1907 (Bloomington, IN, 1988); Thomas E. Drake, Quakers and Slavery in America (New Haven, CT, 1950); William C. Dunlap, Quaker Education in Baltimore and Virginia Yearly Meetings ... (Philadelphia, 1936).

24. Rowntree was of British nativity but had lived in the United States for most of his adult life. He had been a hardware dealer in New York before moving to Iowa to take up farming. See Rowntree to W. E. Whiting, 1/25/1865, AMA \#41027; Rowntree to M. E. Strieby, 3/29/1865, AMA \#41059; 1860 Federal cen- 
from Primrose, taught in Natchez, Mississippi, from 1863 to $1865 .^{25}$ Jehu Lewis, from Marshalltown, taught from 1864 to 1869 , and perhaps longer, in Williamsburg, Virginia, and Charlotte, North Carolina. ${ }^{26}$

The only non-Quaker teacher whose antislavery antecedents can be documented is Alma Baker, a 36-year-old experienced teacher from Quasqueton. She first applied to the AMA for a position in one of its southern black schools through her minister, Rev. George Grinnell, with whose family she had long boarded. Grinnell was apparently known in Quasqueton for his own antislavery stance; the local census taker listed Grinnell as a Congregationalist minister in the 1860 manuscript census, then scrawled, "Worse than a negro."27 Grinnell described Baker as having "allways been thoroughly Antislavery in her views." In her own application to the AMA some months later, Baker wrote, "My feelings and sympathies have ever been with the African race, and I believe they can be elevated intellectually, morally and religiously with any other people or nation, and that to produce that will require patient toil and sacrifice." After Baker had taught for a year in a black school in Missouri, Grinnell died; Baker applied to the AMA again, remarking, "Since I am again cast homeless in the world, I would gladly seek a home and a place of usefulness among that class of people with whom

sus schedule, State of Iowa, Cedar County, Springdale Township 1207/1232, p. 179; and many letters from Rowntree to Abram M. Taylor, 1862-1864, in Abram M. Taylor Papers, Haverford College, Haverford, PA.

25. Friends Freedmen's Association, "Minutes of Instruction Committee," vol. 1, 4/6/1864, in Department of Records, Philadelphia Society of Friends; Second Annual Report of the Board of Directors of the Northwestern Freedmen's Aid Commission (Chicago, 1865), 16; 1870 Federal census schedule, State of Iowa, Lee County, Harrison Township, Primrose Post Office, 146.

26. Friends Freedmen's Association, "Minutes of Instruction Committee," vol. 1, 4/6/1864; Freedmen's Friend 1 (December 1864), 21; ibid. 1 (April 1866), 105; ibid. 1 (December 1867), [116]; "Report of Allan Rutherford," 29 August 1868, Letters Received, Superintendent of Education for North Carolina, Bureau of Refugees, Freedmen, and Abandoned Lands, National Archives. Lewis may well have taught longer, but we lose track of him after 1869.

27. 1860 Federal census schedule, State of Iowa, Buchanan County, Liberty Township, 284/276, p. 523. Alma Baker was listed as a boarder in the Grinnell household. Whether Rev. George Grinnell was related in any way to Iowa's famous abolitionist, Josiah B. Grinnell, is not known. 
I have been so long in sympathy." She continued to teach African American children in Missouri and Cairo, Illinois, for a total of four years, 1863 to $1867 .^{28}$

At least three of Iowa's wartime teachers died as a direct result of their work in the South. S. F. and Mary Vanatta, parents of seven children, were teaching in Vicksburg, Mississippi, for the United Presbyterian Church when they were shot by Confederate soldiers. S. F. Vanatta had been a minister in Washington and Brighton, Iowa. ${ }^{29}$ Henry J. Heilman, who took a year off from his college studies to work with the former slaves in Pine Bluff, Arkansas in 1863-64, contracted camp fever as he was preparing to return to his home in Camanche, and died within days of arriving there, barely 20 years old ${ }^{30}$ In addition, Angeline Emmons, a young Quaker from Oskaloosa, who began teaching African American students in Kirkwood, Missouri, late in 1866, died there on 16 February 1869 at 24 years of age. ${ }^{31}$

DURING THE WAR YEARS, as noted earlier, 28 Iowans taught in the South; 21 went south in 1863-64 alone. Nineteen served in 1865-66. A year later, in the 1866-67 school year, the state reached its high point in the black education movement, sending 36 teachers south. After that, the numbers declined to 16 by $1870-71$, to 10 by $1874-75$, and to 5 in the last year of Re-

28. George Grinnell to "Dear Sir," 1/6/1863, AMA \#40847; Alma Baker to S. S. Jocelyn, 10/1/1863, AMA \#40896; Baker to Jocelyn, 8/15/1864, AMA \#40981; AMA, 18th Annual Report, 1864, 27; AMA, 19th Annual Report, 1865, 28; AMA, 20th Annual Report, 1866, 41; American Missionary 11 (April 1867), 77; 1860 Federal census schedule, State of Iowa, Buchanan County, Liberty Township, 284/276, p. 523.

29. [Warren], Reports and Extracts Relating to Colored Schools, 34-35; Minutes of the Sixth General Assembly of the United Presbyterian Church of North America (n.p., 1864), 48; Ralph Wilson McGranahan, ed., Historical Sketch of the Freedmen's Missions of the United Presbyterian Church, 1862-1904 ([Knoxville, TN], 1904), 17, 20; 1860 Federal census schedule, State of Iowa, Benton County, 7/7, p. 162.

30. AMA, 18th Annual Report, 1864, 25 (misidentified there as Mr. S. J. Heilman); Zenas C. Bradshaw to George Whipple, 7/2/1864, AMA \#40969.

31. "Book of Proceedings, Iowa Yearly Meeting Interests of Freedmen" (Records Room, Iowa Yearly Meeting of Friends, Oskaloosa), 28, entry for 10/24/1866 (hereafter IYMF, "Book of Proceedings"); Friends Review 22 (1869), 651; 1860 Federal census schedule, State of Iowa, Keokuk County, Prairie Township, $17 / 18$, p. 738. 
construction. In all, between 1862 and 1876 at least 108 Iowans taught in the schools for the freedpeople. ${ }^{32}$ By comparison, perhaps as many as 9,000 teachers served during those same years nationwide, a majority hailing from the northern states. More than 2,000 of them were in the southern black schools in 186667 ; the movement peaked in 1869-70 with more than 2,500 teachers, then dropped rapidly to fewer than 900 by $1874-75 .^{33}$

Most of Iowa's teachers served in the South for one or two years, about the average time teachers taught in northern rural schools in that era. Even those such as Amanda Maltby Messenger, a Grinnell teacher of long experience who turned down a teaching position in Illinois because "my heart is set upon the work among the neglected ones of our own country," managed only two years in an AMA school in Beaufort, North Carolina, before returning to northern schools. ${ }^{34}$

There were, however, notable exceptions: teachers who spent many years working with the freedpeople. Most of those who dedicated significant portions of their lives to southern black education were older, more mature teachers before they entered the work. Esther W. Douglass, for example, was an experienced teacher from Decorah, already 42 years old when she took her first position with the AMA. After her first two years of work at Ogeechee, near Savannah, Georgia, she noted to the association that a select school in Decorah was importuning her to return, offering her "more than double the remuneration" the AMA could pay its teachers. Yet, she concluded, "I believe that I can do more good among the Freedmen and my interest in them is so strong I cannot bear to think of engaging in another work."

32. States of origin are known for over 81 percent of all of the teachers in the Freedmen's Teacher Project database. If the remaining teachers were distributed among the states proportionately with those whose homes are known, up to 24 more teachers might also have been from Iowa, since Iowans made up 1.6 percent of all teachers whose homes are known. We suspect, however, that the number that might be added is a good deal lower, probably not more than ten.

33. Data compiled from the Freedmen's Teacher Project files.

34. Mrs. B. Y. [Amanda M.] Messenger to E. M. Cravath, 8/28/1871, AMA \#41271; American Missionary 16 (May 1872), [97]; ibid. 17 (September 1873), 194. Messenger attended Oberlin College in $1847-48$, so it is likely that she was over 40 years old when she taught in North Carolina. 75th Anniversary General Catalogue of Oberlin College, 638. 
And she didn't. She taught in African American schools from Virginia to Georgia and into Tennessee until she was 80. As historian Joe M. Richardson observed, she "taught, cajoled and loved black children for thirty-six years. ${ }^{\prime 35}$

Darius and Rebecca Bowles, Quakers from Wiscotta, were in their late 30 s when they began teaching at Booneville, Missouri, in 1869. Two years later they moved to Sedalia, Missouri, where they taught together for another decade. Rebecca retired in 1880 because of poor health, but Darius continued to work in black education. In 1882 he became principal of Hobson Normal Institute, a black normal school in Parsons, Kansas, created in that year by the Iowa Yearly Meeting of Friends. He remained at Hobson until his death in 1890. Together the Bowleses devoted 32 years to the intellectual growth of black students. ${ }^{36}$

Another Quaker couple, William P. and Luzina L. Hastings, nearly 40 years of age, and their daughter, Elmira Jane Hastings, moved from Dallas County to Maryville, Tennessee, in 1871, to take over the Quaker-sponsored Maryville Freedmen's Normal Institute, he as principal, Luzina and Elmira as teachers. It is unclear how long Luzina and Elmira taught, but William continued as principal of the school for 20 years. ${ }^{37}$

35. Ephriam Adams, "To all whom it may concern," 8/3/1864, AMA \#40977; Esther W. Douglass to George Whipple, 9/3/1866, AMA \#41132C-5; AMA, 19th Annual Report, 1865, 19; AMA, 20th Annual Report, 1866, 29; American Missionary 11 (April 1867), 75; ibid. 14 (June 1870), 125; ibid. 15 (May 1871), [97]; ibid. 16 (May 1872), [97]; ibid. 17 (September 1873), 194; 1870 Federal census schedule, State of Tennessee, Davidson County, 84/103; Richardson, Christian Reconstruction, 178. Douglass died on 8 August 1916; see obituary in American Missionary 71 (April 1917), 36.

36. Minutes of the Iowa Yearly Meeting of Friends, 1870, 1871, 1872; Willard Heiss, Encyclopedia of American Quaker Genealogy, vol. 7, Abstract of the Records of the Society of Friends in Indiana, 6 parts (Indianapolis, 1981), 6:45; Francis Charles Anscombe, "The Contribution of the Quakers to the Reconstruction of the Southern States" (Ph.D. diss., University of North Carolina, 1926), 249; Nelson Case, ed., History of Labette County, Kansas and its Representative Citizens (Chicago, 1901), 200-201 (misspells Bowles as Boles); Joanna Bowles Mott, comp., Ephraim Bowles: His Quaker Heritage (Des Moines, 1954), 92.

37. Minutes of the Iowa Yearly Meeting of Friends, 1871, 18; Heiss, Abstract, 4:71; Stafford Allen Warner, Yardley Warner, the Freedmen's Friend: His Life and Times (Didcot, England, 1957), 15, 223; "The William Wade Hinshaw Index to Iowa Quaker Meeting Records: Orthodox Records," typescript photocopy, William Penn University, Oskaloosa, Iowa, vol. 2, p. 29; Charles W. Cansler, Three Generations: The Story of a Colored Family of East Tennessee (n.p., 1939), 39. 


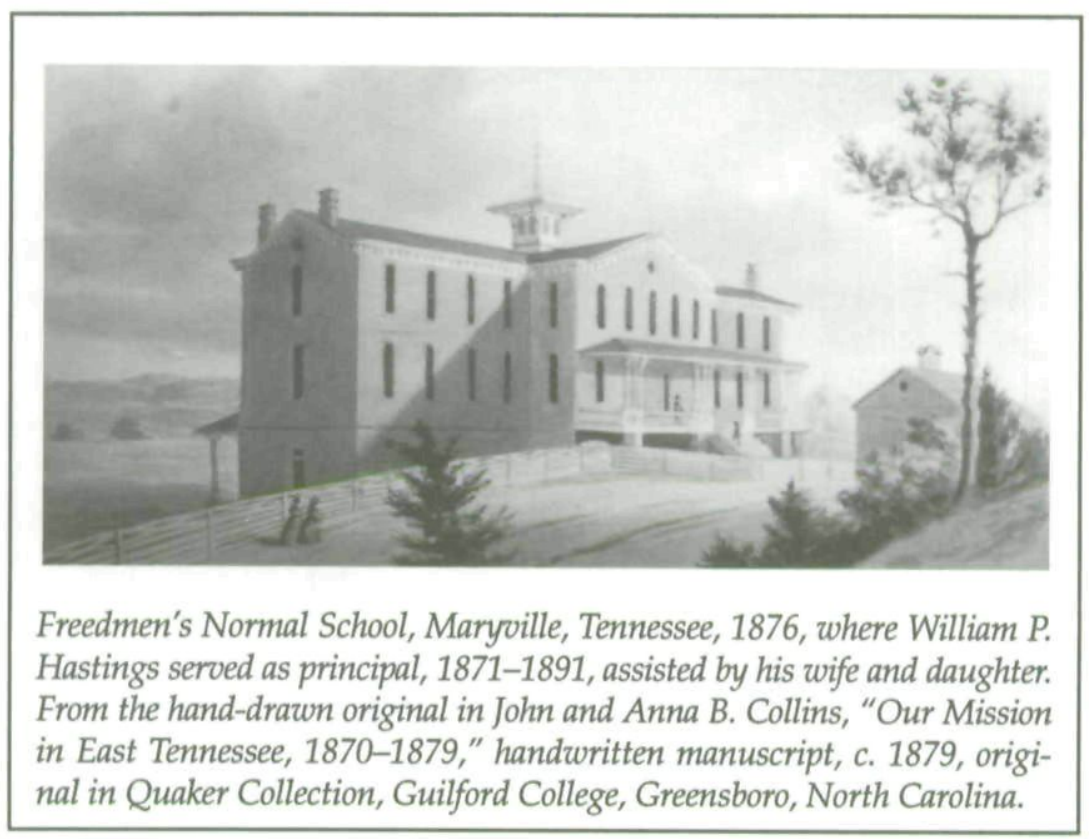

The Tade family-Ewing, Amanda, and their two adult children, James and Molly-from Utica taught in African American schools in Memphis and Chattanooga, Tennessee, for at least 22 years combined before the end of Reconstruction, and Molly and Amanda taught longer, while Ewing spent a portion of his time as the superintendent of schools in Hamilton County, Tennessee. Ewing, a graduate of Grinnell College, was 38 when he first taught in a school for the freedpeople; his wife was $34 .^{38}$

The teachers in the southern black schools faced difficult teaching and living conditions. In the early years of the southern black education effort, the challenges ranged from inadequate schoolrooms to a chronic lack of textbooks, blackboards, and writing material. Teachers worked with classes of a hundred or more students ranging in age from young children

38. AMA, 19th Annual Report, 1864, 30; AMA, 20th Annual Report, 1865, 36; American Missionary 11 (April 1867), 76; ibid. 12 (April 1868), 77; ibid. 13 (May 1869), 103; ibid. 14 (June 1870), 125; ibid. 15 (May 1871), 99; ibid. 16 (May 1872), 99; ibid. 17 (September 1873), 197; C. Stuart McGehee, "E. O. Tade, Freedmen's Education, and the Failure of Reconstruction in Tennessee," Tennessee Historical Quarterly 43 (1984), 376-89. 
through grandparents. Thomas C. Haines, a young Quaker teacher from Le Grand, for example, wrote about his school in St. Joseph, Missouri, in spring 1866.

We now have only one school with about one hundred in regular attendance, though we have more on the roll. We expect soon to open another school, and my present assistant will teach it. We would have opened it before now, but could not get a house, and are now waiting for the colored Baptist Church to be furnished. We are teaching at present in the African M. E. Church, and only have one room, and that so crowded that one can hardly find seats for them. We have no desks but sit on long benches as closely packed as they can sit together. ${ }^{39}$

A different sort of challenge was the possibility of violence from southern whites, particularly after the rise of the Ku Klux Klan. Isaac T. Gibson, a Quaker from Salem, and for two years the busy agent of the Iowa Yearly Meeting of Friends' Committee on the Interests of the Freedmen, was threatened by a mob in St. Louis. ${ }^{40}$ Springdale's Fordyce Grinnell, teaching in Fulton, Missouri, for Gibson's committee, had his school furnishings, stove, and windows destroyed by southern white opponents of black education. Yet Grinnell persevered, teaching in Fulton for three years; during his last year, his younger sister Loueza joined him as a teacher. ${ }^{41}$

As the southern economy began to recover from the war, conditions in black schools improved, at least within the larger

39. [Friends'] Freedmen's Record 1 (March 1866), 10. See also Christian Record 5 (30 December 1865), 205; IYMF, “Book of Proceedings," November 1866, p. 15. By 1870 , Haines had returned to Iowa and was teaching in Le Grand. See 1870 Federal census schedule, State of Iowa, Marshall County, Le Grand Township, Le Grand PO, 93/93, p. 373.

40. Friends Review 20 (2 March 1867), 429; Freedmen's Record 1 (March 1866), 49; American Missionary 11 (November 1867), 252; IYMF, "Book of Proceedings," passim. By 1870, Gibson had become an Indian agent: 1870 Federal census schedules, State of Iowa, Henry County, Salem Township, 39/39, p. 304.

41. Friends Review 20 (3/2/1867), 429; IYMF, "Book of Proceedings," 10/24/1866, p. 27; ibid., 9/11/1867, p. 42; Minutes of the Iowa Yearly Meeting of Friends, 1869. By 1870, Fordyce and Loueza had returned to Springdale, where Fordyce was teaching school. See 1870 Federal census schedule, State of Iowa, Cedar County, Springdale Township, 3/3, p. 339. Fordyce and Loueza were the children of Jeremiah Grinnell; whether they were related in any way to Iowa's famous abolitionist, Josiah B. Grinnell, or to Rev. George Grinnell, from Quasqueton, Iowa, is not known. 
towns and cities of the South. By the early 1870s, for example, two 25-year-old Oberlin graduates from Tabor had become principals of two well-equipped secondary schools for African Americans in Alabama. John M. McPherron administered the Swayne School in Montgomery, Alabama, from 1871 to 1875, and John Morgan Cumings became principal of the Burrell School in Selma, Alabama, in 1874. Each managed a school with more than 460 secondary students; each superintended six teachers and a matron, all females. ${ }^{42}$ In 1872 John Keep Nutting of Glenwood, a 40-year-old Williams College graduate, became president of Tougaloo University, in Mississippi, for two years. He had a dozen faculty members in a school on 500 acres of land; two of his faculty members, S. C. and Emma G. Osborn, like McPherron and Cumings, hailed from Tabor. ${ }^{43}$ Swayne, Burrell, and Tougaloo were among the more than 125 secondary and higher schools created for southern African Americans before the end of Reconstruction, in an era when a secondary education was attained by a minority of students, white as well as black, throughout the nation. ${ }^{44}$

42. American Missionary 16 (May 1872), 99; ibid. 17 (September 1873), 196; ibid. 19 (February 1875), 32; AMA, 28th Annual Report, 1874, 46; 75th Anniversary Catalogue of Oberlin College, 240, 634. McPherron was later president of Occidental College in Los Angeles; his alumni records at Oberlin make no mention of his work among the freedpeople. Cumings remained in the South only one year.

43. American Missionary 17 (September 1873), 200; AMA, 28th Annual Report, 1874, 41; General Catalogue of the Officers, Graduates, and Non-Graduates of Williams College, 1930 (Williamstown, MA, 1930), 88; The Williams Obituary Record (Williamstown, MA, 1916-1919), 382. It appears that Nutting did not complete his second year as president, 1873-74, though the details are not clear.

44. Ronald E. Butchart and Amy F. Rolleri, "Secondary Education and Emancipation: Secondary Schools for Freed Slaves in the American South, 1862-1875," Paedagogical Historica (forthcoming 2003). In recent years, historians have revised upward their estimates of the proportion of youths who attended modern high schools and have added rich detail to that history, but they agree that secondary school remained the experience of a small minority until the twentieth century. The traditional source on the early high school is Edward A. Krug, The Shaping of the American High School, 1880-1920 (Madison, WI, 1969). Among more recent work, see Maris A. Vinovskis, "Have We Underestimated the Extent of Antebellum High School Attendance?" History of Education Quarterly 28 (1988), 551-67; William J. Reese, The Origins of the American High School (New Haven, CT, 1995); Reed Ueda, Avenues to Adulthood: The Origins of the High School and Social Mobility in an American Suburb (Cambridge, 1987). 
None of the Iowa teachers were prominent individuals before they went into the South. They went from the obscurity of everyday nineteenth-century lives to serve in obscurity; most apparently returned to peaceful obscurity. A very few gained a modicum of renown, however. Hastings, Bowles, and Nutting established and took on leadership roles in advanced schools for African American students. Isaac Gibson, agent and teacher for the Committee on Concerns of the Freedmen of the Iowa Yearly Meeting of Friends, became a federal Indian agent to the Osage tribe in 1869. He found himself powerless to win for the Osage the barest token of what the government had promised in treaty talks, and resigned in $1875 .{ }^{45}$ Lorenzo D. Lewelling, a Quaker from Salem, Iowa, taught in Mexico, Missouri, immediately after the Civil War for one year before graduating from Whittier College. After graduation, he distinguished himself as the first superintendent of the Girls Reform School of Iowa, 1869-1884. He later moved to Kansas, where he was attracted to populism, was elected governor of Kansas on the Populist ticket in 1892, and eventually embraced socialism. ${ }^{46} \mathrm{John} \mathrm{M}$. McPherron and Ewing $\mathrm{O}$. Tade both became college presidents later in life, at Occidental College (California) and Tusculum College (Tennessee), respectively. ${ }^{47}$ Finally, Laura Ellen Miles, a Quaker from West Branch who taught among the freedpeople for one year in Mt. Vernon, Missouri, when she was 23, took an Iowa orphan into her home years later when she was living in Newberg, Oregon. The orphan was Herbert Hoover, later to become the nation's thirty-first president. ${ }^{48}$

45. Ray Miles, "'Give Us Our Catholic Priests': The Osage Plea for Freedom of Religion," Chronicles of Oklahoma 66 (1988), 52-63.

46. 1870 Federal census schedule, State of Iowa, Lee County, Cedar Township, p. 10; Douglas Wertsch, "Iowa's Daughters: The First Thirty Years of the Girls Reform School of Iowa, 1869-1899," Annals of Iowa 49 (1987), 77-100; Peter H. Curtis, "Lorenzo D. Lewelling: A Quaker Populist," Quaker History 61 (1972), 113-15.

47. John M. McPherron file, Grads and Formers Collection, Oberlin College Archives, Oberlin College; McGehee, "E. O. Tade," 387.

48. Hulda Hoover MacLean, Ancestors of Herbert Hoover (n.p., 1995), 21; Hoover Genealogy, entry for Laura Ellen Miles Minthorn, B6-115, box 12, Herbert Hoover Presidential Library. 
THE FEW SURVIVING STORIES of Iowans at work in the southern schools, and the stories that can be pieced together from fugitive, partial details of the lives of these ordinary people, provide only a portion of the mosaic of Iowa's teachers to the freedpeople. A more complete portrait can be created by turning to the prosopographic record, the faceless but valuable details about individuals and groups buried in church and bank records, manuscript census returns, vital records, city directories, and other underutilized resources. Those sources add shading, depth, and detail, particularly when the information they provide is compared with the teachers from other northern states.

The Iowa teachers differed in some important ways from what is known about the freedpeople's educators elsewhere. Most notably, only one Iowan was an African American, while black teachers made up an astounding one-third or more of all the freedmen's teachers. ${ }^{49}$ Still, in another sense Dennis Thompson, the only black Iowan to work in the southern black schools, did constitute a fairly accurate reflection of the state's racial makeup: the 5,762 black Iowans in 1870 represented 0.5 percent of Iowa's population, while Thompson represented nearly 1 percent of the state's teachers in the South. He had been born in Missouri in 1846, but had been raised in Iowa; by 1872 he was teaching school on a plantation near Vicksburg, Mississippi. ${ }^{50}$

Gender was less a factor among lowa's teachers than it was among most other freedmen's teachers from the North, though it remained important. Among teachers from across the North,

49. In 1870, 322,000 African Americans, or less than 7 percent of all African Americans, lived north of the Mason-Dixon line, and constituted less than 2 percent of the total northern population, yet accounted for more than 10 percent of the northern teachers. When northern black teachers are combined with the high number of literate southern blacks who taught, black teachers account for over 30 percent of all the teachers; they account for 48 percent of all teachers for whom race is now known, so it is likely that the total number of black teachers will rise as further data is gathered. Data from the Freedmen's Teachers Project. See also Maxine D. Jones, "'They Are My People': Black American Missionary Association Teachers in North Carolina during the Civil War and Reconstruction," Negro Educational Review 36 (1985), 78-89.

50. U.S. Secretary of the Interior, A Compendium of the Ninth Census (June 1, 1870), 4 vols. (Washington, DC, 1872), 4:8, 12; Register of Signatures, Freedmen's Savings and Trust Co., Vicksburg Branch, Application \#6134, 1/2/1872. We can find nothing more about Thompson. 
white women were twice as likely to teach in the freedpeople's schools as white men (there was almost no gender difference in the participation rates of northern black teachers, by contrast). ${ }^{51}$ In Iowa, the gender difference was less pronounced. About 57 percent of the teachers were women, 43 percent were men. ${ }^{52}$ Like women elsewhere, the white women from Iowa served longer than Iowa men, an average of 2.4 years per woman, 2.0 years per man between 1862 and the end of Reconstruction. ${ }^{53}$ Iowa's status as a primarily agricultural, industrially underdeveloped state probably contributed to the greater participation of men, compared to more easterly states; farmers could find time to travel a few hundred miles into the South to teach in the winter, while the economic forces that marginalized women's economic contributions to the domestic economy in the East had not fully developed in the agricultural West, just as the mid- to late-century feminization of teaching had proceeded much more fully in eastern states than in places such as Iowa by the $1860 \mathrm{~s}$ and $1870 \mathrm{~s}^{54}$

In other ways, the Iowa teachers were much like those from the rest of the North. The Iowans were, on average, not young people with some free time to spend before taking on more permanent responsibilities. Nineteenth-century northern public school teachers were usually quite youthful, but the average age when the Iowa teachers began working with the freed slaves was nearly 29; men were about a year older, women a year younger. ${ }^{55}$ Those figures correspond almost exactly to the aver-

51. Butchart, "Perspectives," 18-19.

52. Sixty-two of the Iowa teachers (57.4\%) were women; 46 (42.6\%) were men.

53. Preliminary data from the Freedmen's Teachers Project; see also Butchart, "Perspectives," 19-23.

54. Mary P. Ryan, Womanhood in America: From Colonial Times to the Present (New York, 1975), 19-191; Julie A. Matthaei, An Economic History of Women in America: Women's Work, the Sexual Division of Labor, and the Development of Capitalism (New York, 1982), 101-56; John L. Rury, "Who Became Teachers?: The Social Characteristics of Teachers in American History," in American Teachers: Histories of a Profession at Work, ed. Donald Warren (New York, 1989), 9-48; Geraldine Jonçich Clifford, "Man/Woman/Teacher: Gender, Family and Career in American Educational History," ibid., 293-343; Joel Perlmann and Robert A. Margo, Women's Work? American Schoolteachers, 1650-1920 (Chicago, 2001).

55. Birth year is known for 69 of the 108 Iowa teachers, including 35 women and 34 men. Women averaged 27.8 years of age when they began teaching in 
age among all northern white freedpeople's teachers. Black teachers tended to be younger, about 25-coincidentally, Dennis Thompson's age when he began to teach. ${ }^{56} \mathrm{~A}$ few went south at what now seems a fairly youthful age; Lorenzo Lewelling from Salem, William Phar from Mt. Pleasant, and Sarah Jacobs from Keokuk County were each 18 when they ventured south. Yet each had family or friends to rely upon. Phar taught in a town not distant from an older sister, 23-year-old Ella Phar. Lewelling traveled to Missouri with two other Quaker teachers from Salem, Anna H. Stinsman and Ruth I. Pickering. Sarah Jacobs taught in Booneville, Missouri, with Darius and Rebecca Bowles, fellow Quakers. For every Iowa freedpeople's teacher under 25 years of age, there was one over 30 .

Further, the Iowa teachers, like those elsewhere, were not from privileged homes, for the most part. Two were from homes with combined personal and real wealth of over $\$ 16,000$, but the median combined wealth was less than $\$ 6,000$. Nearly one-third of those whose relative wealth is known were worth less than $\$ 1,200$ in 1870 . Most were farmers or the children of farmers, though Rebecca Johnson's father, at the high end of the wealth scale, owned a woolen factory, several were ministers, and two were the children of blacksmiths. Several were, of course, schoolteachers themselves, never an adequately compensated profession, and particularly not in mid-nineteenth-century America. In their social class origins, Iowa's teachers were very much like northern white public schoolteachers. ${ }^{57}$

the South; men averaged 29.9; the average across both genders was 28.8 . On the youthfulness of nineteenth-century public school teachers in the North, see Rury, "Who Became Teachers?" 10, 28.

56. Butchart, "Perspectives," 19 , reports a slightly higher average age than reported here. Work on the Freedmen's Teachers Project since publication of that essay has resulted in a lower average age. Future refinements will disaggregate northern and southern teachers, which may yield a somewhat higher average age for northern teachers.

57. Both the 1860 and 1870 federal censuses asked census takers to ascertain the real estate and personal estate of each head of household and each adult child at home. We located 47 of the Iowa teachers in one or both censuses. Because many of the teachers had relatively common names, it was not always possible to be certain that individuals found in the manuscript census were the individuals included in this study; when identification was uncertain, the in- 
The Iowa teachers, then, like those elsewhere who went into the South to work with the ex-slaves, took time from established routines to answer the call for service to the oppressed. Some went as families-Darius and Rebecca Bowles, for example, or Elias and Mary Jane Jessup from Hardin County, who traveled to Pine Bluff, Arkansas in 1864-65 with their two children. The Jessups were followed to Pine Bluff the next year by Ann M. and Thomas S. Byers from Fairfield, who, with their children, spent three years there. Joseph and Elisabeth McConnell had six children and a farm in Grand Mound, but still managed to spend three years in Vicksburg and Davis Bend, Mississippi, teaching for the United Presbyterian Mission to the Freedmen. Anamosa's August C. and Mary Stickle, farmers and teachers, worked together for the AMA at Swan Lake, Arkansas, in 1867-68. ${ }^{58}$

Others left wives or husbands for shorter or longer periods to aid the former slaves. Eliza Gruwell left her husband in Tipton while she taught for two years in Washington, Missouri. Jesse Pickett, a farmer from Cedar County, left his wife and five children to spend a winter teaching in Fulton, Missouri. ${ }^{59}$

dividual data has not been included in the study. On the social class characteristics of public school teachers, see Rury, "Who Became Teachers?" 20-23.

58. For Bowles, see n. 36 above. For Jessup, see Second Annual Report of the Board of Directors of the Northwestern Freedmen's Aid Commission (Chicago, 1865), 14; Hinshaw, "Hinshaw Index, Orthodox Records," 3:132. For the Byers family, see T. S. Byers to William Colby, 23 May 1867, Endorsements Sent, Records of the Superintendent of Education for the State of Arkansas, Bureau of Refugees, Freedmen, and Abandoned Lands, microfilm, roll 1. For the McConnells, see 1870 Federal census schedule, State of Iowa, Clinton County, Welton Township, 100/102, p. 452; McGranahan, Sketch of the Freedmen's Missions, 17, 20; United Presbyterian Church, Minutes of the 6th General Assembly, 1864, 48; ibid, 1865, p. 184. For the Stickles, see 1870 Federal census schedule, State of Iowa, Jones County, Cals Township, Sangwulty Post Office, 58/63; American Missionary 12 (April 1868), 78. Mary Stickle is not included in the American Missionary's list of teachers, but was teaching with her husband; see "Teacher's Monthly Reports" for May, July, August, and September 1867, Records of the Superintendent of Education for the State of Arkansas, Bureau of Refugees, Freedmen, and Abandoned Lands, roll 5; Larry Wesley Pearce, "Enoch K. Miller and the Freedmen's Schools," Arkansas Historical Quarterly 31 (1972), 322.

59. For Gruwell, see 1870 Federal census schedule, State of Iowa, Cedar County, Gower Township, 78/81, p. 243; Minutes of the Iowa Yearly Meeting of Friends, 1868, 21. For Pickett, see 1870 Federal census schedule, State of Iowa, Cedar County, Farmington Township, 58/64, p. 209; Minutes of the Iowa Yearly Meeting of Friends, 1872, 15. 
ON ONE CRUCIAL DIMENSION, however, the Iowa teachers stand out from the freedpeople's educators elsewhere in the North: Iowa's participation in southern black education was low compared to states further east. Iowa's 108 teachers represented just one teacher for every 11,000 people in the state in 1870. By contrast, in Connecticut, for example, the freedpeople's teachers were one of every 2,500 of the population, and in Ohio they were one of every 5,600. In general, the older, more settled states sent a greater proportion of their population to the South, with New England and Ohio having the highest proportions, the middle states and Michigan sending a lower proportion, and Indiana, Illinois, Wisconsin, and Iowa coming in still lower. ${ }^{60}$

The very low rate of participation in the education movement among the freed slaves calls for explanation, particularly in the face of the work of Robert Dykstra. In an exquisitely researched volume, he has demonstrated that in a quartercentury, from the decade before the Civil War to the middle of Reconstruction, Iowa transformed itself "from perhaps the most racially conservative free state in the Union into one of its most progressive. ${ }^{\prime 61}$ How is it, then, that a state with such a positive record on issues of race did less than virtually any other state to secure the freedpeople's intellectual emancipation?

The answer lies in the recognition that embracing egalitarianism as an ideology was relatively easy, requiring little more than voting for legislators who reflected that egalitarianism or voting positively in referenda on issues touching on race. Mobilizing an egalitarian spirit to active participation on behalf of the oppressed was something else entirely. As Dykstra demonstrates, religious affiliations and places of birth count heavily in explaining a laudable, but ultimately passive, egalitarianism; those same affiliations and places of birth count for much less when explaining active work in solidarity with African Americans to shore up a fragile emancipation. Specifically, Dykstra found that from the late 1850s onward, those supporting the excision of whites-only language from the state's fundamental law, the

60. Minnesota, even less settled, had a participation rate less than half that of Iowa, at one teacher for every 23,000 residents. 1870 population statistics from U.S. Secretary of the Interior, Compendium of the Ninth Census, 4:8.

61. Dykstra, Bright Radical Star, 238. 
TABLE 1

RELIGIOUS AFFILIATIONS OF IOWA FREEDPEOPLE'S TEACHERS

\begin{tabular}{lr}
\hline Baptist & 1 \\
Congregationalist & 9 \\
Methodist $^{\text {Presbyterian }}$ Painstream evangelical $^{\mathrm{b}}$ & 4 \\
Muaker & 12 \\
Qua & 57 \\
\hline
\end{tabular}

$n=103$

"Includes Old School, New School, and United Presbyterians. The Old and New School wings merged in 1870 .

bIndividuals whose affiliation has not yet been identified, but who were commissioned by the American Missionary Association, a primarily Congregationalist organization that hired only members in good standing of evangelical churches, primarily Methodists, Wesleyan Methodists, Presbyterians, Congregationalists, and Baptists.

Source: Iowa subset, Freedmen's Teachers Project Data Files

repeal of the black exclusion law, and the guarantee of black suffrage tended to be affiliated with particular religions: Presbyterians, "upstate" Methodists, Congregationalists, Quakers, Lutherans, and Episcopalians. Racially progressive citizens also tended to have roots in New England, New York's Burned-Over District, or Ohio's Western Reserve, and had settled particularly in Iowa's northeastern counties. ${ }^{62}$

Those factors do not correlate well with the pattern of Iowans attracted to active participation in Reconstruction. First, Presbyterians, Methodists, and Congregationalists made up a minority of Iowa's teachers among the freedpeople; Lutherans and Episcopalians did not participate at all (see table 1). ${ }^{63}$ What is remarkable about the Iowans who worked in the South is the highly disproportionate contribution of Quakers. Although Quakers constituted less than 2 percent of the state's total population, over half of the teachers (57 of 108) were Quakers. If that small religious group had not sent such a large proportion of its people into the South, Iowa's contribution would have been minuscule. ${ }^{64}$

62. Ibid., 171-92, 216-70, 253, and 289-90.

63. So far as we have been able to determine to date, out of more than 8,250 teachers nationwide, not one was Lutheran. Episcopalians from the East Coast did work among the freedpeople, though at very low rates.

64. In 1870 there were about 17,000 Quakers in Iowa, up from about 9,000 in 1865. Thus, Iowa Quakers contributed one teacher for every 170 to 300 Quak- 
TABLE 2

BIRTHPLACES OF IOWA FREEDPEOPLE'S TEACHERS AND THEIR PARENTS

\begin{tabular}{lcc}
\hline Place of Birth & Teacher & Parent \\
\hline New England & 6 & 3 \\
New York & 2 & 6 \\
Old Northwest & 30 & 15 \\
Middle States & 7 & 5 \\
Iowa and Illinois & 9 & 9 \\
South & 0 & 13 \\
\hline
\end{tabular}

Teachers: $n=67$

Parents: $n=38$

Source: Iowa subset, Freedmen's Teacher Project Data File

Second, while the majority of the teachers or their parents did come from the traditional geographical sources of racially progressive attitudes-New England and the areas to the west populated largely by emigrants from New England-a significant minority came from the mid-Atlantic states of New Jersey and Pennsylvania and from the South (see table 2). Further, many of the teachers or their parents emigrated from southern Ohio and Indiana, not the more northerly areas of the Old Northwest known for their New England, and presumably more antislavery, immigrants. Extant sources do not indicate whether the teachers or their parents who came to Iowa from New York were from the Burned-Over District or other areas of the state. ${ }^{65}$ One-third of the teachers or their parents came from

ers in the state, compared to the overall rate of one teacher per 11,000 residents of the state as a whole. U.S. Secretary of the Interior, Compendium of the Ninth Census, 4:520; the 1865 estimate is from Thomas D. Hamm, "The Divergent Paths of Iowa Quakers in the Nineteenth Century," Annals of Iowa 61 (2002), 125. The Quakers were disproportionately represented everywhere in the freedpeople's aid movement, though it is our sense that the disproportion was most pronounced in Iowa.

65. Both Dykstra and we are handicapped in determining birthplaces by the fact that the federal census asked only the state of birth, disallowing the sort of fine-grained determinations needed to know if a New Yorker had been born in the Hudson River valley or in the Burned-Over District, or if an Ohioan was born near Cleveland in the Western Reserve or near Cincinnati or the southwestern counties. However, for a minority of the Quaker teachers, the massive genealogical work of William Wade Hinshaw and others provides important information. All of the Quakers who were born in Ohio and Indiana were born 
areas not known for abolitionist leanings, and only nine of the rest-those from New England-were unambiguously from a region noted for its abolitionism. Nativity was, at best, a weak indicator of who would choose to serve the freedpeople.

Third, the geographical distribution of the teachers within Iowa did not conform well to the geography of political egalitarianism that Dykstra documents. The cities and counties that stand out in Iowa's racially progressive history in the third quarter of the nineteenth century embraced generally the northeastern two-thirds of the state, with the southern tier or two of counties, and some counties along the Mississippi River, less prone to race liberalism. Yet Iowa's teachers were drawn disproportionately from southeastern counties, with a heavy preponderance coming from counties that had a strong Quaker presence (see map). Henry County, the site of the earliest Quaker migrations, along with Cedar and Mahaska Counties, sites of important Quarterly meetings, accounted for over half of the Quaker teachers. ${ }^{66}$ The northeast quadrant of counties, solidly among the most progressive counties from the 1850s onward (Dubuque and, occasionally, Allamakee Counties excepted), could not muster a tenth of the teachers. ${ }^{67}$

The teachers were drawn from only 32 of the state's 99 counties. The distribution cannot be fully explained by population densities; while the teachers came predominantly from counties with a population greater than 15,000 inhabitants in 1870 , they represented only 26 of the 37 counties with that density. With the exception of Fremont County in the far southwest corner of the state, the only counties contributing five or more teachers lay well east of Des Moines and south of Cedar Rapids, with most of the remaining teachers coming from a scattering of other eastern counties.

Despite their reputation for liberalism on issues of race, then, few Iowans contributed to the most significant issue of race in their day, the full emancipation of the nation's former

in southern counties in those two states. See William Wade Hinshaw and Thomas Worth Marshall, Encyclopedia of American Quaker Genealogy, 8 vols. (Ann Arbor, MI, 1950); "Hinshaw Index to Iowa Quaker Meeting Records."

66. Hamm, "Divergent Paths of Iowa Quakers," 127-39.

67. Dykstra, Bright Radical Star, esp. 145, 215, 228, and 235. 
MAP

DISTRIBUTION OF IOWA FREEDPEOPLE'S TEACHERS BY COUNTY

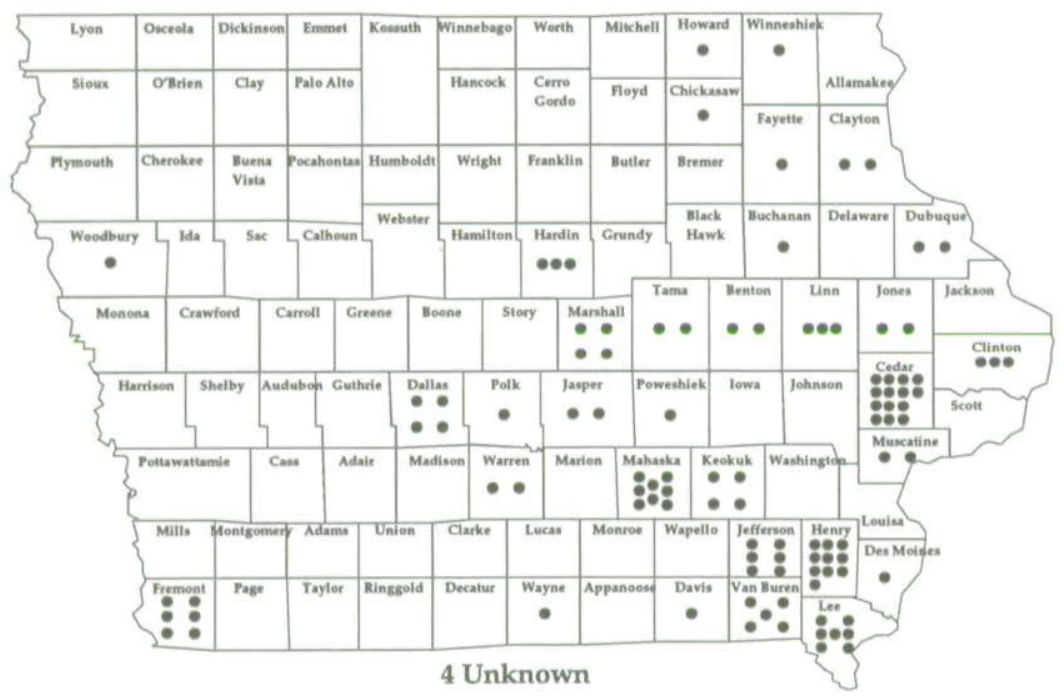

slaves. So, if Iowa's "egalitarian moment" does not adequately explain the work of those Iowans who chose to teach southern African Americans, what does? ${ }^{68}$

It appears that a combination of strong Quaker influence and the length of time a county had been settled partially explains the influences on individuals who decided to devote at least a few months, a couple of years, or much of their lives extending the tenuous promise of emancipation. Decades of committed action by Quakers to provide education and other civil rights to African Americans, often in the teeth of opposition from their neighbors, explains the most, of course, given the disproportionate number of Quakers among the teachers.

THE TEACHERS FROM IOWA, then, do not fit the traditional portrait of the northern teachers who taught the South's ex-slaves from 1861 to the end of Reconstruction. The northern teachers are typically portrayed as young, white, single New

68. Ibid., chap. 12. 
England women, generally from more privileged backgrounds, with abolitionist leanings, from mainstream Protestant churches. That stereotype has begun to suffer as a result of historical research in recent years, and the Iowa teachers contribute to the sense that it must be radically revised. The teachers were far more likely to be black than realized heretofore, though the Iowa band of teachers included only one of the 2,500 black teachers identified so far. They were not young by nineteenthcentury standards, but were mature, well-established farmers, teachers, ministers, housewives, and shopkeepers. Many were single, but a significant number were married. New England roots counted for less than the traditional portrait suggests. Women outnumbered men, yet among Iowa teachers the difference was not great. Taken together, they did not come from wealthy Iowa homes. Far too little is yet known about the teachers to speak definitively about their motivations, yet commitment to racial justice seems to have played a minor part except among the one group known for its historic testimony for racial equality. ${ }^{69}$ Finally, it was not Iowa's mainstream Protestants who led the struggle for schools for the former slaves, but a tiny sect, Iowa's Quakers.

The quiet movement in which these teachers participated to bring schools, books, and teachers to the freed slaves peaked in the late 1860s, only a half-decade after Emancipation, then declined. Nationally, after the early 1870 s only the largest denominational organizations were still supporting southern black schools, particularly the American Missionary Association and freedmen's aid societies within the Methodist, Presbyterian, and Baptist denominations, followed closely by one small sect, the Quakers, who remained active into the $1920 \mathrm{~s}^{70}$

69. Ronald E. Butchart, "Mission Matters: Mount Holyoke, Oberlin, and the Schooling of Southern Blacks, 1861-1917," History of Education Quarterly 42 (2002), 1-17.

70. Butchart, Northern Schools, Southern Blacks, and Reconstruction, 197-208; Richardson, Christian Reconstruction; Brawley, Two Centuries of Methodist Concern. On the continuing work of Quakers, see particularly Thomas C. Kennedy, "Southland College: The Society of Friends and Black Education in Arkansas," Arkansas Historical Quarterly 42 (1983), 207-38. The Iowa Yearly Meeting of Friends continued its work in black education until Hobson Normal Institute closed in 1891. See Case, History of Labette County, Kansas, 201. 
There is, finally, an irony in the story of the Iowa freedpeople's teachers, one that reflects a similar irony across all of the northern states. Iowa readily mustered more than 70,000 young men to spend one to four years in America's most brutal war; the state lost more than 10,000 of those young men to gain the freedom of the slaves and preserve the Union. ${ }^{17}$ Yet in the vital work of securing legal emancipation through intellectual emancipation and shaping the racial and social contours of the future Union through committed work in reconstructing the South, Iowa could muster only 108 men and women to spend, on average, a bit over two years. Imagine what the nation might have gained if Iowa and the North had invested even a tenth as much to secure the peace as it sacrificed to win the war.

70. Leland L. Sage, A History of Iowa (Ames, 1974), 153-54. 
Copyright of Annals of Iowa is the property of State of Iowa, by \& through the State Historical Society of Iowa and its content may not be copied or emailed to multiple sites or posted to a listserv without the copyright holder's express written permission. However, users may print, download, or email articles for individual use. 